\title{
Systematic implications of seed coat morphology in Campanulaceae Juss.
}

\author{
Zeinab A. Elwan, Abdel-Monaim I.I. Aboel-Atta*, \\ Mohamed H.A. Loutfy ${ }^{*}$ and Ehab A. Kamel ${ }^{*}$
}
Department of Botany, Faculty of Science, Ain Shams University, Abassia Cairo, Egypt
*Department of Biological Sciences and Geology, Faculty of Education, Ain Shams University, Roxy - Cairo, Egypt.

Zeinab A. Elwan, Abdel-Monaim I.I. Aboel-Atta, Mohamed H.A. Loutfy and Ehab A. Kamel. 2006. Systematic implications of seed coat morphology in Campanulaceae Juss. Taeckholmia 26: 35-62.

\begin{abstract}
In the present study the seed coat micromorphology of 51 accessions of the Campanulaceae $s$. $l$. were investigated via SEM, the selected OTU's include accessions representing 11 genera and 35 species of the subfamilies: Campanuloideae and Lobelioideae. This study is an attempt to investigate variation between the species and the taxonomic relationships between them. Variations in seed coat micro-sculpture supported the monophyly of the family, favored the retention of Lobelia in the Campanulaceae, showed a relatively isolated nature of Edraianthus serbicus and suggested that the genus Campanula as is currently constituted may be polyphyletic and needs further studies. The study also recorded a relatively high degree of polymorphism within the seed shape and seed coats of the different accessions of the same species, thus suggesting more future studies for their re-evaluation.
\end{abstract}

Key words: Campanulaceae, numerical analysis, seed coat, SEM.

\section{Introduction}

The Campanulaceae s. l., bellflower or Lobelia family is a natural nearly cosmopolitan family, with centers of diversity located mainly in temperate regions of the old world (Mabberley, 1997; Shulkina et al., 2003 and Conser et al., 2004). It is widely distributed in the temperate and sub-tropical regions and in the mountainous tropics, comprises 65 genera and 2200 
species (Judd et al., 1999) or 82 genera and 2000 species (Mabberley, 1997).

De-Candolle (1830) treatment is one of the first taxonomic treatments of the Campanulaceae; in his monograph he recognized two groups corresponding two tribes: Wahlenbergieae and Campanuleae. Later classification systems have traditionally followed the arrangements of Boissier (1875 \& 1888) and Schönland (1889) together with the refinements of Charadze (1949, 1970 \& 1976), Fedorov (1972), Kolakovsky (1987), Eddie (1997) and Takhtajan (1997).

The Campanulaceae $s$. $l$. is some times divided into several families, the Campanulaceae s. str., Lobeliaceae, Cyphiaceae, Cyphonocarpaceae and Nemacladaceae (Bremer, 1994). The three last families are separated from the Lobeliaceae. Lobeliaceae were distinguished from Campanulaceae by Takhtajan (1997), but treated within the Campanulaceae by both Cronquist (1981 \& 1988) and Thorne (1992).

Heywood (1993) treated Lobelia and allied genera in a separate family and stated that the family Campanulaceae $s$. str. (excluding the aberrant genera Cyphia, Pentaphagma and Sphenoclea) is rather natural and homogenous but its subdivision presents serious problems because there seems to be little correlation between the various diagnostic features. Based on the morphology of the ovary and capsule, he recognized three subtribes within the Campanulaceae s. str. which however, do not necessarily represent separate phyletic (evolutionary) lines: (1) Campanulinae; the ovary is inferior and carpels superposed on calyx teeth, the fruit is a capsule opening laterally, some times indehiscent and in one genus a berry (genera include Campanula, Adenophora and Legousia). (2) Wahlenberginae; the ovary may be inferior or semi-inferior to superior, the carpels are superposed on calyx teeth, the fruit is capsule opening on the top and in one genus a berry (genera include Wahlenbergia, Codonopsis and Jasione). (3) Platycodinae; the ovary is inferior to semi-inferior, the carpels alternate with the calyx teeth and the fruit is a capsule opening terminally or laterally (the type-genus is Platycodon).

However, in Schönland (1889), most widely accepted taxonomic treatment of the Campanulaceae, the family is treated as one entity with three distinguished subfamilies (Lammers, 1992). These are consecutively Campanuloideae (which contains Campanula, Wahlenbergia, Phyteuma, Jasione and Platycodon), Cyphioideae (Cyhia and Nemacladus) and Lobelioideae (including Lobelia, Centropogon and Siphocampylus). The 
Campanuloideae (with radially symmetrical flowers and nonconnate anthers) is considered monophyletic on the basis of invaginating hairs on the upper portion of the style and the Lobelioideae constitutes a clade based on their connate anthers, resupinate flowers and one- to two-lipped corolla with a variously developed slit in the upper lobe (developmentally adaxial, but abaxial when flower is resupiate). Analysis of $r b c L$ sequence variation also supports the monophyletic concept of both subfamilies (Cosner et al., 1994). However, the circumscription of the Campanulaceae, up till now, has been controversial (Reveal, 1999 and Cosner et al., 2004). In certain instances it is difficult to discern the rationale behind tribal placement of individual genera (Eddie et al., 2003).

APG (2003) showed that no conclusive evidence can either favor the separation of Lobelia and allied genera in separate families or retaining them in the Campanulaceae. In their opinion, the option of recognizing Campanulaceae and Lobeliaceae as separate families is retained, although grouping them in one family is preferred. Takhtajan (1997) divided the Campanulaceae s. str. into four subfamilies. Subfamily Cyananthoideae includes the genera Cyananthus, Codonopsis, Campanumoea, Leptocodon and Platycodon; subfamilies Ostrowskioideae and Canarinoideae are monogeneric. Subfamily Campanuloideae consists of 12 tribes and includes all remaining genera. Eddie (1997) divided the family into two major tribes, since the differences between them do not warrant subfamilial status. Platycodoneae is subdivided into subtribes: Ostrowskiinae, Cyananthinae, Echinocodinae, Codonopsinae, Platycodinae, Campanumoeinae and Canarininae, while Campanuleae comprise Wahlenberginae, Jasioneinae, Musschiinae, Azorininae and Campanulinae.

Although the monophyly of the Campanulaceae $s$. $l$. was supported by morphology and $r b c L$ sequences (Cosner et al., 1994). There is considerable disagreement among all prior classifications of Campanulaceae. Furthermore, there is no common opinion about generic and specific limits or higher relationships among the major sub-divisions of the family. Taxonomic problems in this family can be explained by the fact that nearly all of earlier classifications had a geographical rather than biological basis (Eddie et al., 2003). Judd et al. (1999) stated that generic delimitations are often problematic; Campaula, Centropogon and Lobelia are certainly not monophyletic. Shulkina et al. (2003) suggested that Edraianthus is closely 
related to Campanula and not to genera with apical capsule dehiscence and should be excluded from the sub-tribe Wahlenberginae.

Members of the Campanulaceae and their presumed ancestors were subjected to several studies covering various aspects as phylogeny, histology, chemotaxonomy, phytogeography and breeding systems (Stace \& James, 1996; Petterson, 1997; Tu et al., 1998; Lewis et al., 1999; Tyler, 1999; Jonsell et al., 2000; Stephenson et al., 2000; Teslov, 2000 and Buss et al., 2001; Eddie et al., 2003; Shulkina et al., 2003; Conser et al., 2004 and others).

In the present study the seed coat micromorphology of 51 accessions comprising the two subfamilies Campanuloideae and Lobelioideae was investigated. The study is an attempt to investigate species differences and the taxonomic relationships between them. The relationships between the same taxa were formerly examined by Kamel (2005) using SDS-PAGE of seed protein profiles. Previous studies on seed micromorphology and anatomy of certain taxa of Campanulaceae $s$. $l$. are numerous e.g. Mededovic (1980), Belyayev (1986), Lakoba (1991), Murata (1992), Shrestha \& Kravtsova (1992), Murata (1995), Werker (1997) Hong \& Pan (1998) and Buss et al. (2001).

\section{Materials and Methods}

The plant material used in this study were 51 accessions of the Campanulaceae $s$. $l$. comprising 11 genera and 35 species, representing the two subfamilies Campanuloideae (48 accessions) and the Lobelioideae (three accessions). Seeds were kindly supplied by some European botanical gardens and Universities (Table 1).The voucher specimens are kept at the Herbarium of the Department of Biological Sciences and Geology, Faculty of Education, Ain Shams University (CAIA), Cairo, Egypt (CAI).

For SEM observations, dried mature seeds were mounted on brass stubs and coated with a thin layer of gold using JEOL-JFCL 1100E ion sputtering. Coated seeds were examined and photographed on a JEOL-JSM5300 SEM with an accelerating voltage of $15 \mathrm{KV}$ at the Electron Microscopic Unit, Faculty of Science, Ain Shams University. The terminology of Stearn (1966) and Barthlott (1981 \& 1990) were used to describe the SEM aspects of seed coat. 
Systematic implications of seed coat morphology in ...

Table 1. The studied taxa of the Campanulaceae $s$. $l$. The suprageneric classification is after Schönland (1889) and the sections of the European Campanula after Tutin (1976).

\begin{tabular}{|c|c|c|c|c|c|c|}
\hline No & $\begin{array}{c}\text { Taxa } \\
\end{array}$ & Subfamily & Tribe & Subtribe & section & Source \\
\hline 1 & $\begin{array}{l}\text { Adenophora liliifolia (L.) Ledeb. } \\
\text { ex A. DC. }\end{array}$ & Campanuloideae & Campanuleae & campanulinae & - & PBG \\
\hline 2 & Campanula alliariifolia Willd. & Campanuloideae & Campanuleae & campanulinae & - & BAW \\
\hline 3 & C. alpina Jacq. & Campanuloideae & Campanuleae & campanulinae & Campanula & BAW \\
\hline 4 & C. barbata $\mathrm{L}$. & Campanuloideae & Campanuleae & campanulinae & Campanula & BAW \\
\hline 5 & C. carpatica Jacq. & Campanuloideae & Campanuleae & campanulinae & Rapunculus & BAW \\
\hline 6 & C. cochlearifolia Lam. & Campanuloideae & Campanuleae & campanulinae & Campanula & BAW \\
\hline 7 & C. collina M. B. & Campanuloideae & Campanuleae & campanulinae & - & BAW \\
\hline 8 & C. erinus $\mathrm{L}$. & Campanuloideae & Campanuleae & campanulinae & Campanula & OBS \\
\hline 9 & C. glomerata $\mathrm{L}$. & Campanuloideae & Campanuleae & campanulinae & campanula & BAW \\
\hline 10 & C. glomerata $\mathrm{L}$. & Campanuloideae & Campanuleae & campanulinae & campanula & PBG \\
\hline 11 & C. glomerata $\mathrm{L}$. & Campanuloideae & Campanuleae & campanulinae & campanula & GPE \\
\hline 12 & C. lactiflora M. B. & Campanuloideae & Campanuleae & campanulinae & rapunculus & PBG \\
\hline 13 & C. lactiflora M. B. & Campanuloideae & Campanuleae & Campanulinae & rapunculus & GPE \\
\hline 14 & C. latifolia $\mathrm{L}$. & Campanuloideae & Campanuleae & Campanulinae & campanula & BAW \\
\hline 15 & C. latifolia $\mathrm{L}$. & Campanuloideae & Campanuleae & Campanulinae & campanula & GPE \\
\hline 16 & C. nobili-macrantha Fisch. & Campanuloideae & Campanuleae & Campanulinae & - & BAW \\
\hline 17 & C. persicifolia $\mathrm{L}$. & Campanuloideae & Campanuleae & Campanulinae & rapunculus & BAW \\
\hline 18 & C. persicifolia $\mathrm{L}$. & Campanuloideae & Campanuleae & Campanulinae & rapunculus & PBG \\
\hline 19 & C. poscharskyana Deg. & Campanuloideae & Campanuleae & Campanulinae & campanula & BAW \\
\hline 20 & C. pyramidalis $\mathrm{L}$. & Campanuloideae & Campanuleae & Campanulinae & campanula & PBG \\
\hline 21 & C. rapunculoides $\mathrm{L}$. & Campanuloideae & Campanuleae & campanulinae & campanula & BAW \\
\hline 22 & C. rapunculoides $\mathrm{L}$. & Campanuloideae & Campanuleae & Campanulinae & campanula & GPE \\
\hline 23 & C. rapaunculus $\mathrm{L}$. & Campanuloideae & Campanuleae & Campanulinae & rapunculus & OBS \\
\hline 24 & C. rhomboidalis $\mathrm{L}$. & Campanuloideae & Campanuleae & Campanulinae & campanula & GPE \\
\hline 25 & C. rotundifolia $\mathrm{L}$. & Campanuloideae & Campanuleae & Campanulinae & campanula & BAW \\
\hline 26 & C. rotundifolia $\mathrm{L}$. & Campanuloideae & Campanuleae & Campanulinae & campanula & GPE \\
\hline 27 & C. sarmatica Ker-Gawl. & Campanuloideae & Campanuleae & Campanulinae & - & OBS \\
\hline 28 & C. sarmatica Ker-Gawl. & Campanuloideae & Campanuleae & Campanulinae & - & GPE \\
\hline 29 & C. scheuchzeri Vill. & Campanuloideae & Campanuleae & Campanulinae & campanula & BAW \\
\hline 30 & C. thyrsoidea $\mathrm{L}$. & Campanuloideae & Campanuleae & Campanulinae & campanula & PBG \\
\hline 31 & C. thyrsoidea $\mathrm{L}$. & Campanuloideae & Campanuleae & Campanulinae & campanula & GPE \\
\hline 32 & C. tommasiniana W. D. J. Koch & Campanuloideae & Campanuleae & Campanulinae & campanula & PBG \\
\hline 33 & C. trachelium $\mathrm{L}$. & Campanuloideae & Campanuleae & Campanulinae & campanula & OBS \\
\hline 34 & C. trachelium $\mathrm{L}$. & Campanuloideae & Campanuleae & Campanulinae & campanula & BAW \\
\hline 35 & C. trachelium $\mathrm{L}$. & Campanuloideae & Campanuleae & Campanulinae & campanula & PBG \\
\hline 36 & C. trachelium $\mathrm{L}$. & Campanuloideae & Campanuleae & Campanulinae & campanula & GPE \\
\hline 37 & $\begin{array}{l}\text { Codonopsis clematidea (Schrenk } \\
\text { ex Fisch. et C. A. Mey.) C. B. } \\
\text { Clarke }\end{array}$ & Campanuloideae & Wahlenbergieae & Wahlenberginae & - & PBG \\
\hline 38 & Edraianthus serbicus Petrovic & Campanuloideae & Wahlenbergieae & Wahlenberginae & - & BAW \\
\hline 39 & Jasione laevis Lam. & Campanuloideae & Wahlenbergieae & Wahlenberginae & - & BAW \\
\hline 40 & J. laevis Lam. & Campanuloideae & Wahlenbergieae & Wahlenberginae & - & PBG \\
\hline 41 & $\begin{array}{l}\text { Legousia speculum-veneris (L.) } \\
\text { Chaix. }\end{array}$ & Campanuloideae & Campanuleae & Campanulinae & - & PBG \\
\hline 42 & Phyteuma orbiculare $\mathrm{L}$. & Campanuloideae & Campanuleae & Campanulinae & - & BAW \\
\hline 43 & $\begin{array}{l}\text { Platycodon grandiflorus (Jacq.) } \\
\text { A. DC. }\end{array}$ & Campanuloideae & Merciereae & Platycodinae & - & BAW \\
\hline 44 & P. grandiflorus (Jacq.) A. DC. & Campanuloideae & Merciereae & Platycodinae & - & PBG \\
\hline 45 & P. grandiflorus (Jacq.) A. DC. & Campanuloideae & Merciereae & Platycodinae & - & GPE \\
\hline 46 & Symphyandra armena A. DC. & Campanuloideae & Campanuleae & Campanulinae & - & BAW \\
\hline 47 & S. zanzegura Lipsky & Campanuloideae & Campanuleae & Campanulinae & - & PBG \\
\hline 48 & Trachelium coeruleum L. & Campanuloideae & Campanuleae & Campanulinae & - & OBS \\
\hline 49 & Lobelia inflata $\mathrm{L}$. & Lobelioideae & - & - & - & BGB \\
\hline 50 & L. siphilitica $\mathrm{L}$. & Lobelioideae & - & - & - & PBG \\
\hline 51 & L. siphilitica $\mathrm{L}$. & Lobelioideae & - & - & - & BGB \\
\hline
\end{tabular}


$\mathrm{BAW}=$ Bundesgarten Alpengarten in Beivedere, Wien, Austeria. $\mathrm{BGB}=$ Botanical Garden of Bonn University, Germany. GPE = Grugpark Essen - Gruga Vogelpark Botanischer Garten, bundesrepublik Deutschland. OBS = Orto Botanico Dell Universita di Siena, Italy. PBG = Universität Potsdam Botanischer Garten, Am Neuen Palais, Potsdam, Berlin, Germany.

For the numerical analysis, the accessions were numbered as in Table 1. The presence or absence of each of the different attributes of whole seed and seed coat micromorphology were treated as a binary character and coded 1 and 0, respectively for computation using the program NTSYS-pc (Rohlf, 1993). The method applied is based on cluster analysis and expresses the relationships between the studied taxa as average taxonomic distance (dissimilarity) in phenograms.

\section{Results}

The SEM features of whole seeds and seed coats of the studied taxa are shown in Plates 1-4. Their attributes are summarized in Table 2. The macromorphological aspects of the studied taxa showed that the seed shape was slightly variable, mainly of an ovate to ellipsoid pattern, the variants included the following: Ovate to oblong, Ovate to ellipsoid, ellipsoid, ovate to fusiform, glubose to ovate, boat shaped to ovate (Table 2 and Plates 1-4).

Concerning the overall pattern of seed coat epidermal cells, the studied taxa showed two distinct morphotypes (reticulate and striate) that often crossed the generic, sectional and specific barriers. The first morphotype possessed isodiametric to slightly tangentially elongated cells. Cells in that morphotype either took a reticulate pattern with hexagonal cells $(C$. carpatica -5 and $C$. pyramidalis -20 ), both belonging to sections Rapunculus and Campanula consecutively or a ruminate pattern $(C$. persicifolia -17 , section Rapunculus), a generally scalariform pattern with irregularly rectangular cells (C. persicifolia -18 , C. tommasiniana -32 , Lobelia inflata -49, L. siphilitica -50, L. siphilitica -51$)$ and finally a pusticulate pattern with rhomboid cells (Edraianthus serbicus -38). The second morphotype (striate) possessed tracheid or fiber shaped very narrow cells often tapering at both ends or taking a narrow rectangular to rod shape. The resulting pattern often ranged from a generally reticulate to scalariform one with rhomboid or rectangular cell shape (when the anticlinal walls are less thick and cell lumen relatively wide) and finally ending in the sulcate or ribbed sulcate pattern (when anticlinal walls are very thick, covering the outer periclinal walls). Several variants of the second morphotype can be 
Systematic implications of seed coat morphology in ...

Table 2. Seed micromorphological aspects of the studied 51 accessions of Campanulaceae.

\begin{tabular}{|c|c|c|}
\hline Characters & Attributes & $\begin{array}{r}\text { Species numbers } \\
\end{array}$ \\
\hline \multirow{6}{*}{$\begin{array}{c}\text { Whole } \\
\text { seed } \\
\text { Shape }\end{array}$} & 1. Ovate to oblong & $4,9,12,22,29,34,37,44 \& 48$ \\
\hline & 2. Ovate to ellipsoid & $\begin{array}{l}1,6,7,8,10,11,13,14,15,20,24,26,28,31 \\
41,42,45,49,50 \& 51\end{array}$ \\
\hline & 3. Ellipsoid & $5,16,23,27,33 \& 39$ \\
\hline & 4. Ovate to fusiform & $25,32,36,40 \& 47$ \\
\hline & 5. Ovate to glubose & $3,17,19,26,35,43 \& 46$ \\
\hline & 6. Boat shaped to ovate & $2,15,18,21,30 \& 38$ \\
\hline \multirow{10}{*}{$\begin{array}{c}\text { Overall } \\
\text { seed } \\
\text { coat } \\
\text { pattern }\end{array}$} & \multicolumn{2}{|l|}{ Morphotype (1): Reticulate pattern } \\
\hline & 7. Reticulate & $5 \& 20$ \\
\hline & 8. Ruminate & 17 \\
\hline & 9. Scalariform & $18,32,49,50 \& 51$ \\
\hline & 10. Pusticulate & 38 \\
\hline & \multicolumn{2}{|l|}{ Morphotype (2): Striate pattern } \\
\hline & 11. Reticulate to scalariform & $\begin{array}{l}1,2,4,6,9,10,11,12,19,25,27,28,29,30,31, \\
33,34,35,37,43 \& 44\end{array}$ \\
\hline & 12. Reticulate scalariform to sulcate & $\begin{array}{l}3,8,13,14,15,16,21,22,24,26,36,39,45 \& \\
46\end{array}$ \\
\hline & 13. Sulcate & $23,40,41,42,47 \& 48$ \\
\hline & 14. Sulcate with transverse bridges & 7 \\
\hline \multirow{19}{*}{$\begin{array}{l}\text { Anticlinal } \\
\text { walls }\end{array}$} & \multicolumn{2}{|l|}{ Shape: } \\
\hline & 15. sinuate & 17 \\
\hline & 16. Slightly rounded & 38 \\
\hline & 17. Straight (in general) & The rest of the studied species \\
\hline & \multicolumn{2}{|l|}{ Thickness degree: } \\
\hline & 18. Very thick & $1,2,5,7,10,11,16,23,41 \& 42$ \\
\hline & 19. Thick & $\begin{array}{l}4,6,8,12,13,14,15,27,28,32,33,36,37,40 \\
43,44 \& 48\end{array}$ \\
\hline & 20. Variable & $\begin{array}{l}3,18,19,20,21,22,24,26,30,31,34,35,39 \\
\& 47\end{array}$ \\
\hline & 21. Relatively thin & $9,17,25,29,45,46,49,50 \& 51$ \\
\hline & \multicolumn{2}{|l|}{ Texture of wall: } \\
\hline & 22. Buttressed & $1,5,7,11,13,17,20,32,37,41,43 \& 44$ \\
\hline & 23. Slightly buttressed to tuberculate & $4,8,14,16,27,28,36 \& 39$ \\
\hline & 24. Striated & 19 \\
\hline & 25. Smooth & $\begin{array}{l}2,3,6,9,10,12,15,21,22,23,24,25,26,29,30 \\
31,33,34,35,40,42,45,46,48,49,50 \& 51\end{array}$ \\
\hline & 26. Illdefined & 38 \\
\hline & 27. Smooth and channeled & 18 \\
\hline & \multicolumn{2}{|l|}{ Level: } \\
\hline & 28. Leveled & 38 \\
\hline & 29 Raised & The rest of the studied species \\
\hline \multirow{9}{*}{$\begin{array}{l}\text { Periclinal } \\
\text { walls }\end{array}$} & \multicolumn{2}{|l|}{ Level: } \\
\hline & 30. More or less flat & $17 \& 27$ \\
\hline & 31. Concave & The rest of the studied species \\
\hline & 32. Variable & 38 \\
\hline & \multicolumn{2}{|l|}{ Texture } \\
\hline & 33. Slightly striate to tuberculate & $4,5,6,8,19,20,27,28,32 \& 49$ \\
\hline & 34. Sulcate & 17 \\
\hline & 35. Ribbed & 38 \\
\hline & 36. Smooth & The rest of the studied species \\
\hline
\end{tabular}




\begin{tabular}{|c|c|c|}
\hline \multirow{9}{*}{$\begin{array}{c}\text { Generalized } \\
\text { diagnostic } \\
\text { features of } \\
\text { seed coat }\end{array}$} & $\begin{array}{l}\text { 37. Uniformly buttressed rectangular } \\
\text { cells }\end{array}$ & 1 \\
\hline & 38. Interwoven very thick walled cells & 41 \\
\hline & $\begin{array}{l}\text { 39. Irregular rhomboid to rectangular } \\
\text { cells }\end{array}$ & $43,44 \& 45$ \\
\hline & $\begin{array}{l}\text { 40. Uneven distribution of warty to } \\
\text { illdefined bodies }\end{array}$ & $46,47 \& 48$ \\
\hline & $\begin{array}{l}\text { 41. Rhomboid to hexagonal elongated } \\
\text { cells }\end{array}$ & $9,10 \& 11$ \\
\hline & $\begin{array}{l}\text { 42. Appearance of spherical bodies on } \\
\text { anticlinal walls }\end{array}$ & $12 \& 13$ \\
\hline & $\begin{array}{l}\text { 43. Intermingled rhomboid and } \\
\text { rectangular cells }\end{array}$ & $14,15,25,26,27,28,30,31,39,40 \& 42$ \\
\hline & $\begin{array}{l}\text { 44. Irregular wall thickenings with few } \\
\text { illdefined bodies }\end{array}$ & $21,22,33,34,35,36,39 \& 40$ \\
\hline & $\begin{array}{l}\text { 45. Rhomboid to irregular cells with } \\
\text { buttresses on the anticlinal walls }\end{array}$ & $37,43 \& 44$ \\
\hline
\end{tabular}

observed, these are: Reticulate to scalariform (21 taxa), reticulatescalariform to sulcate (13 taxa), sulcate (six taxa), sulcate with transverse bridges (one taxon). A remarkable finding in this study was the prevalence of buttressed anticlinal walls in 12 taxa, slightly buttressed in ten taxa, striated in one taxon, smooth and channeled (one taxon), illdefined (one taxon) while smooth anticlinal walls were observed in 27 taxa (Table 2 and Plates 1-4).

The phenogram produced by the analysis of 45 applicable attributes of the seed shape and seed coat micromorphological aspects of the studied accessions is shown in (Fig. 1). The phenogram obtained shows that the examined taxa of the Campanulaceae have an average taxonomic distance (ATD) or total genetic distance of about 3.00. It seems non reasonable to discus the results at OTU's level, so a simplified phenogram was made for the studied 51 accessions in order to construct reasonable taxonomic groups (Fig. 2).

This phenogram shows that the examined OTU's at a dissimilarity level of about 1.50 are divided into two GROUPs: A and B, GROUP A comprises Edraianthus serbicus (only one accession 1/1), Legousia speculum-veneris (only one accession 1/1) and four species of Campanula (out of 23 species); C. collina (1/1), C. poscharskyana (1/1), C. persicifolia $(2 / 2)$ and $C$. sarmatica (1/2). This may indicate the high dissimilarity of these Campanula species from the other examined 19 species of Campanula.

The remaining 44 OTU's are in GROUP B, which is further subdivided at a dissimilarity level of about 1.45 into two Groups. Group $\mathrm{B}_{1}$ includes only Adenophora liliifolia, while Group $\mathrm{B}_{2}$ is further subdivided at a dissimilarity level of about 1.30 into two groups $\left(\mathrm{B}_{2-\mathrm{a}}\right.$ and $\left.\mathrm{B}_{2-\mathrm{b}}\right)$. Group $\mathrm{B}_{2-\mathrm{a}}$ 
comprises only Campanula carpatica (1/1) and C. pyramidalis. The remaining OTU's are within Group B2-b.

At a dissimilarity level of about $1.25 \mathrm{~B}_{2-\mathrm{b}}$ is divided into Group I, which includes Codonopsis and two accessions out of three of Platycodon grandiflorus and Group II, which contains the remaining OTU's. Group II which includes 38 OTU's is further divided into two groups (II-a \& II-b) at the level of about 1.18. group II-a includes Jasione laevis (1/2), Symphyandra armena (1/1), S. zanzegura (1/2), Trachelium coeruleum $(1 / 1)$, the two accessions of Campanula lactiflora (2/2) and $C$. tommasiniana $(1 / 1)$.

On the other hand, group II-b is further subdivided at a dissimilarity level of 1.13 into; group II- $b_{1}$ which comprises two accessions out of three of Campanula glomerata (2/3), while group II- $\mathrm{b}_{2}$ includes the remaining 28 OTU's. Group II- $b_{2}$ is further subdivided into group II- $b_{2-1}$ which includes three species of Campanula; C. glomerata (1/3), C. scheuchzeri (1/1), C. rotundifolia (1/2), Platycodon grandiflorus (1/3) and the three accessions of Lobelia (Fig. 2).

Group II- $b_{2-2}$ is further subdivided into subgroup (i) which includes five species of Campanula; C. barbata (1/1), C. erinus (1/1), C. sarmatica (1/2), C. cochlearifolia (1/1) and $C$. latifolia $(2 / 2)$. On the other hand, subgroup (ii) includes the remaining OTU's; Campanula alliariifolia (1/1), $C$. thyrsoidea (2/2), C. alpine (1/1), C. rotundifolia (1/2), C. rhomboidalis (1/1), C. rapunculoides (2/2), C. trachelium (3/4), C. nobili-macrantha and C. rapaunculus (1/1), in addition to Jasione laevis (1/1) and Phyteuma orbiculare (1/1). 

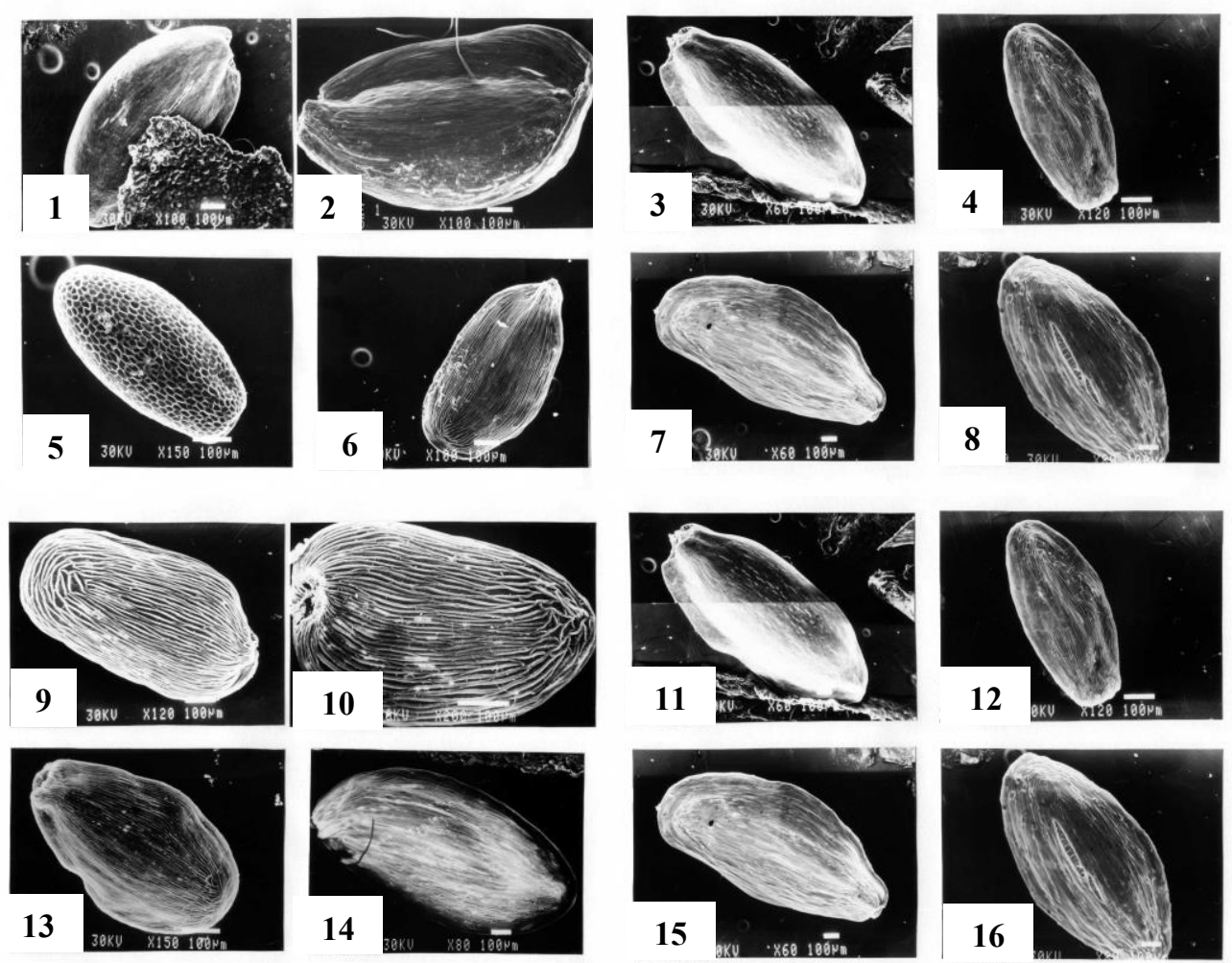

Plate 1. Figs. 1-16 SEM micrographs of the studied taxa of Campanulaceae.

(1) Adenophora liliifolia, (2) Campanula alliariifolia, (3) C. alpine, (4) C. barbata,

C. carpatica, (6) C. cochlearifolia, (7) C. collina, (8) C. erinus, (9) C. glomerata (BAW), (10) C. glomerata (PBG), (11) C. glomerata (GPE), (12) C. lactiflora (PBG), (13) C. lactiflora (GBE), (14) C. latifolia (BAW), (15) C. latifolia (GPE), (16) C. nobilimacrantha. 

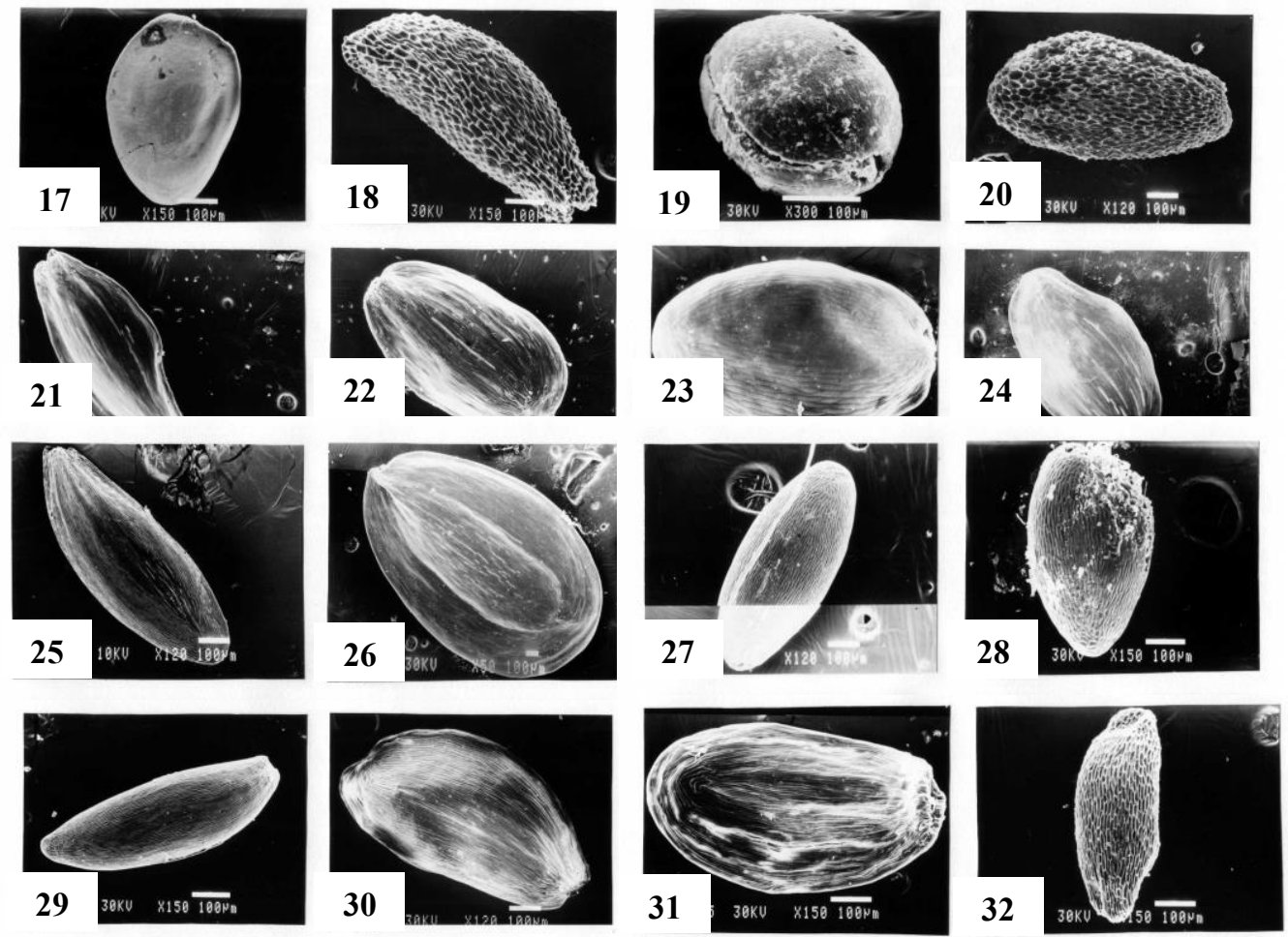

Plate 1 (Cont.). Figs. 17-32 SEM micrographs of the studied taxa of Campanulaceae.

(17) C. persicifolia (BAW), (18) C. persicifolia (PBG), (19) C. poscharskyana, (20) C. pyramidalis, (21) C. rapunculoides (BAW), (22) C. rapunculoides (GPE), (23) C. rapaunculus, (24) C. rhomboidalis, (25) C. rotundifolia (BAW), (26) C. rotundifolia (GPE), (27) C. sarmatica (OBS) and (28) C. sarmatica (GPE), (29) C. scheuchzeri, (30) C. thyrsoidea (PBG), (31) C. thyrsoidea (GPE), (32) C. tommasiniana. 

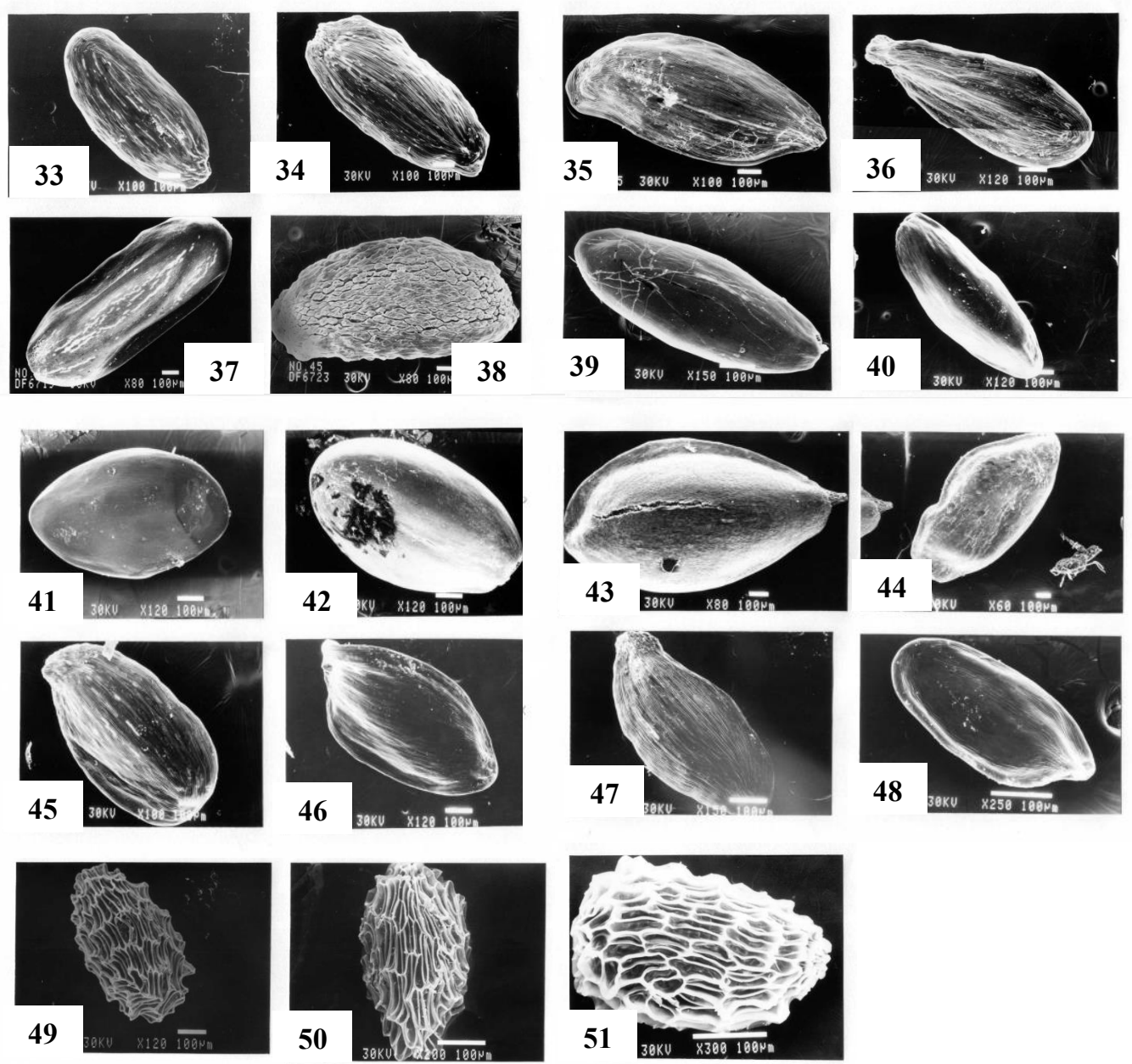

Plate 2. Figs. 33-51 SEM micrographs of the studied taxa of Campanulaceae.

(33) C. trachelium (OBS), (34) C. trachelium (BAW), (35) C. trachelium (PBG), (36) C. trachelium (GPE), (37) Codonopsis clematidea, (38) Edraianthus serbicus, (39) Jasione laevis (BAW), (40) J. laevis (PBG), (41) Legousia speculum-veneris, (42) Phyteuma orbiculare, (43) Platycodon grandiflorus (BAW), (44) P. grandiflorus (PBG), (45) P. grandiflorus (GPE), (46) Symphyandra armena, (47) S. zanzegura, (48) Trachelium coeruleum, (49) Lobelia inflata, (50) L. siphilitica (PBG) \& (51) L. siphilitica (BGB) 

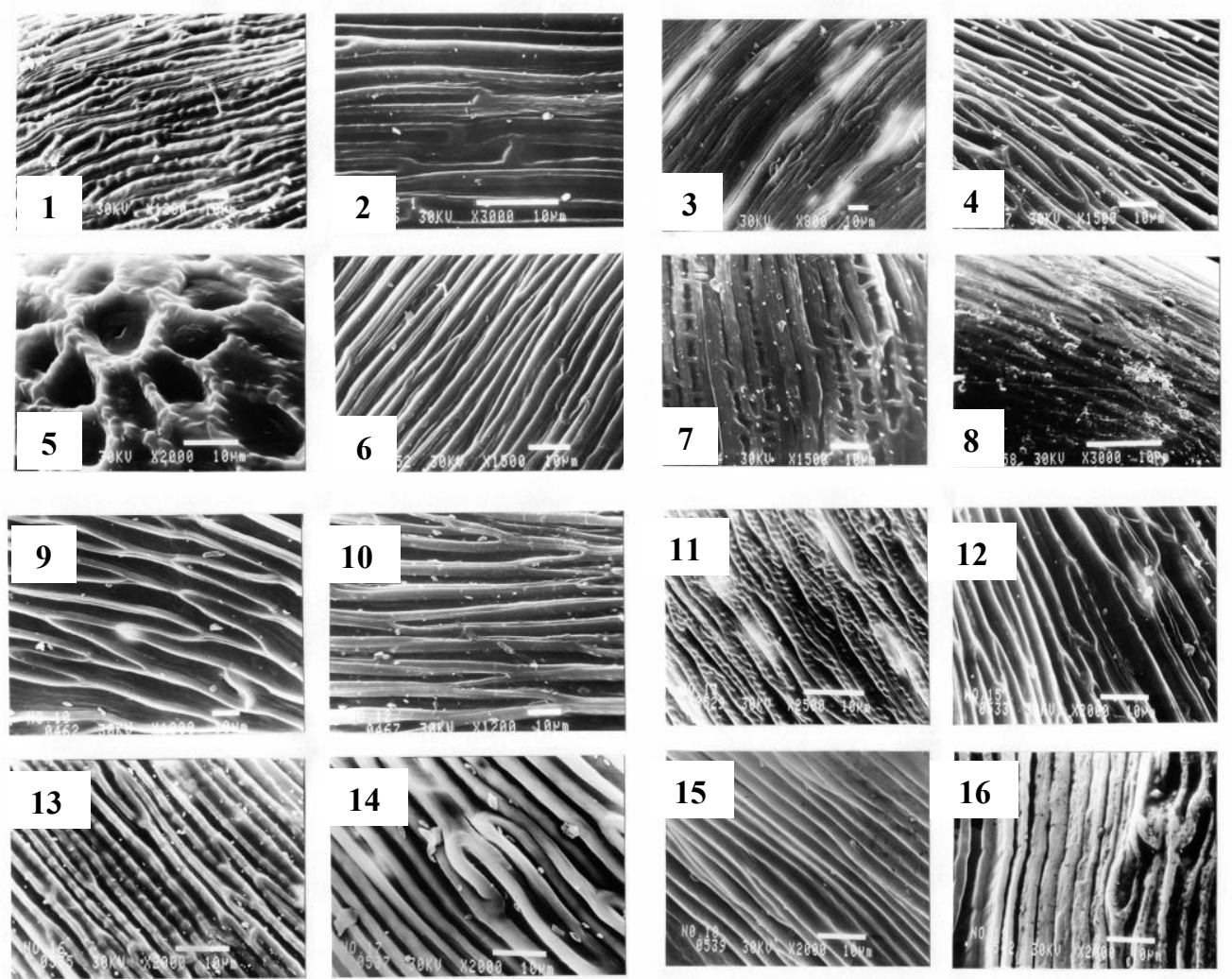

Plate 3. Figs. 1-16 SEM micrographs of the studied taxa of Campanulaceae.

(1) Adenophora liliifolia, (2) Campanula alliariifolia, (3) C. alpine, (4) C. barbata, (5) C. carpatica, (6) C. cochlearifolia, (7) C. collina, (8) C. erinus, (9) C. glomerata (BAW), (10) C. glomerata (PBG), (11) C. glomerata (GPE), (12) C. lactiflora (PBG), (13) C. lactiflora (GBE), (14) C. latifolia (BAW), (15) C. latifolia (GPE), (16) C. nobilimacrantha. 

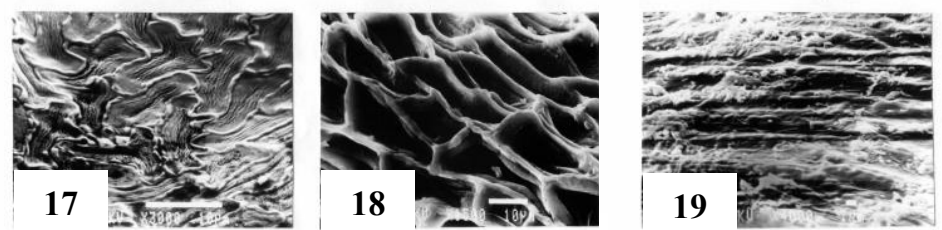

19
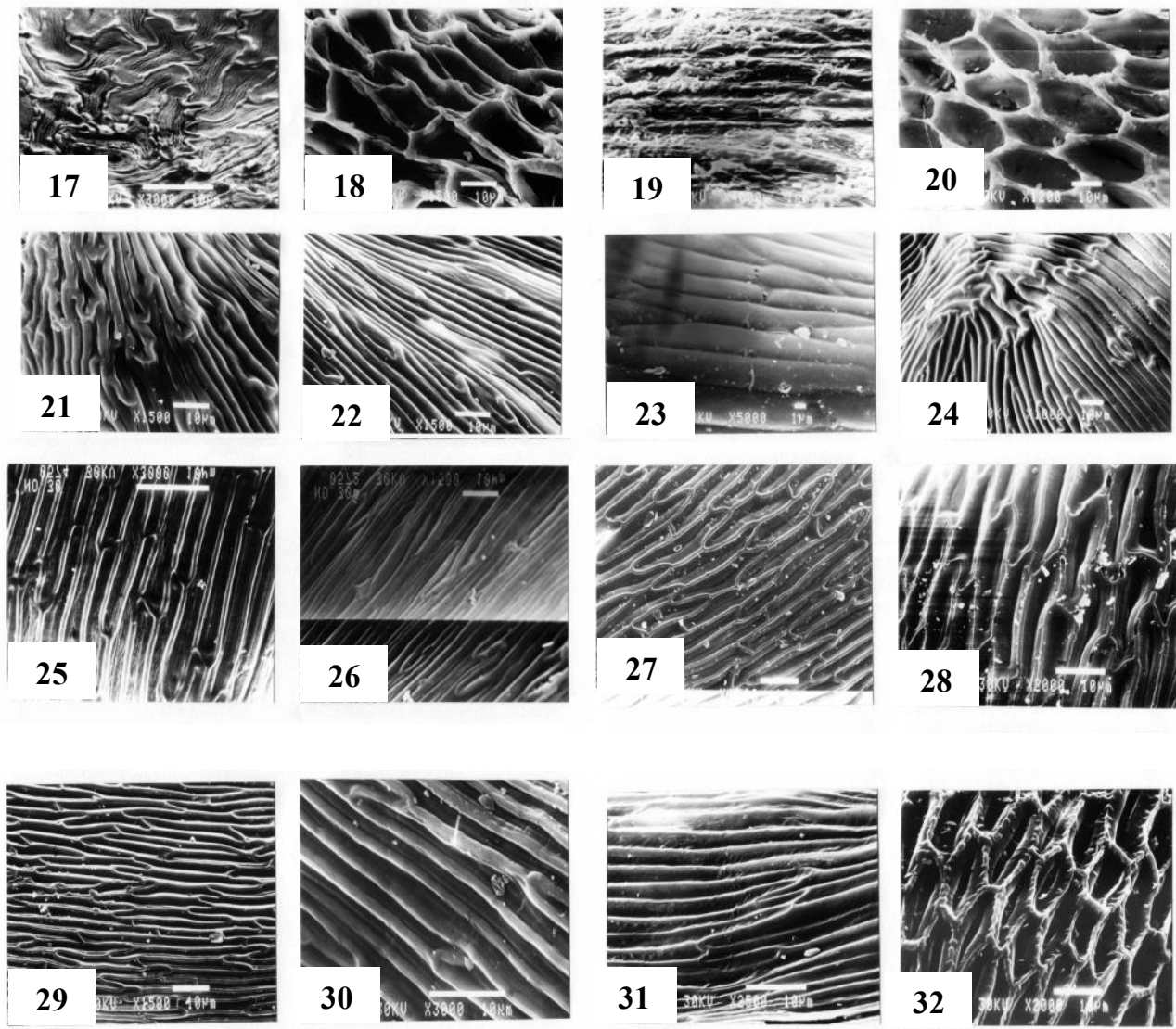

Plate 3 (Cont.). Figs. 17-32 SEM micrographs of the studied taxa of Campanulaceae.

(17) C. persicifolia (BAW), (18) C. persicifolia (PBG), (19) C. poscharskyana, (20) C. pyramidalis, (21) C. rapunculoides (BAW), (22) C. rapunculoides (GPE), (23) C. rapaunculus, (24) C. rhomboidalis, (25) C. rotundifolia (BAW), (26) C. rotundifolia (GPE), (27) C. sarmatica (OBS) and (28) C. sarmatica (GPE), (29) C. scheuchzeri, (30) C. thyrsoidea (PBG), (31) C. thyrsoidea (GPE), (32) C. tommasiniana. 

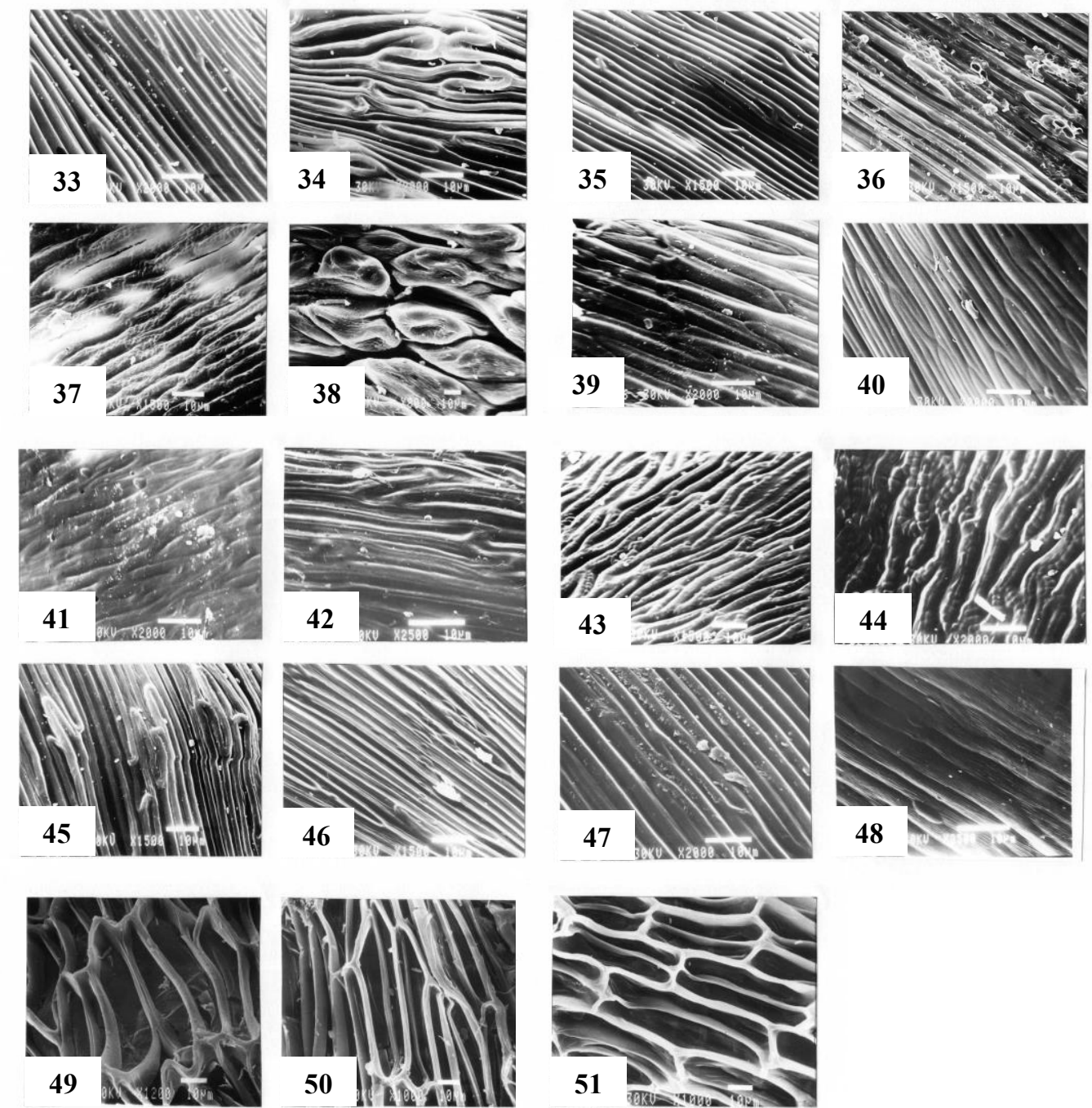

Plate 4. Figs. 33-51 SEM micrographs of the studied taxa of Campanulaceae.

(33) C. trachelium (OBS), (34) C. trachelium (BAW), (35) C. trachelium (PBG), (36) C. trachelium (GPE), (37) Codonopsis clematidea, (38) Edraianthus serbicus, (39) Jasione laevis (BAW), (40) J. laevis (PBG), (41) Legousia speculum-veneris, (42) Phyteuma orbiculare, (43) Platycodon grandiflorus (BAW), (44) P. grandiflorus (PBG), (45) P. grandiflorus (GPE), (46) Symphyandra armena, (47) S. zanzegura, (48) Trachelium coeruleum, (49) Lobelia inflata, (50) L. siphilitica (PBG) \& (51) L. siphilitica (BGB). 
Average Taxonomic Distance (Dissimilarity)

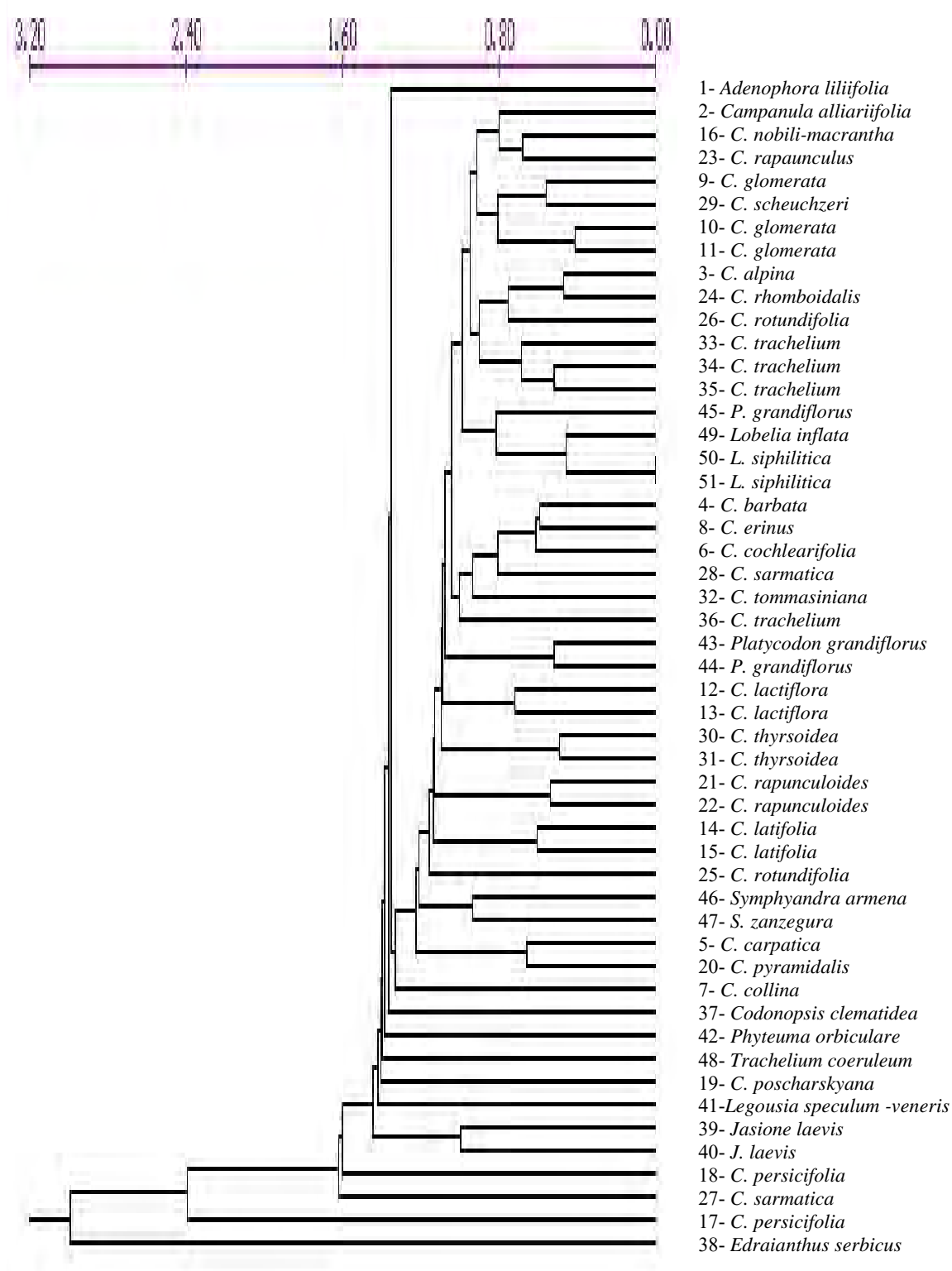

Fig. 1. UPGMA - phenogram based on coding of 45 attributes obtained from seed scan micromorphology of 51 accessions of Campanulaceae. 
Systematic implications of seed coat morphology in ...

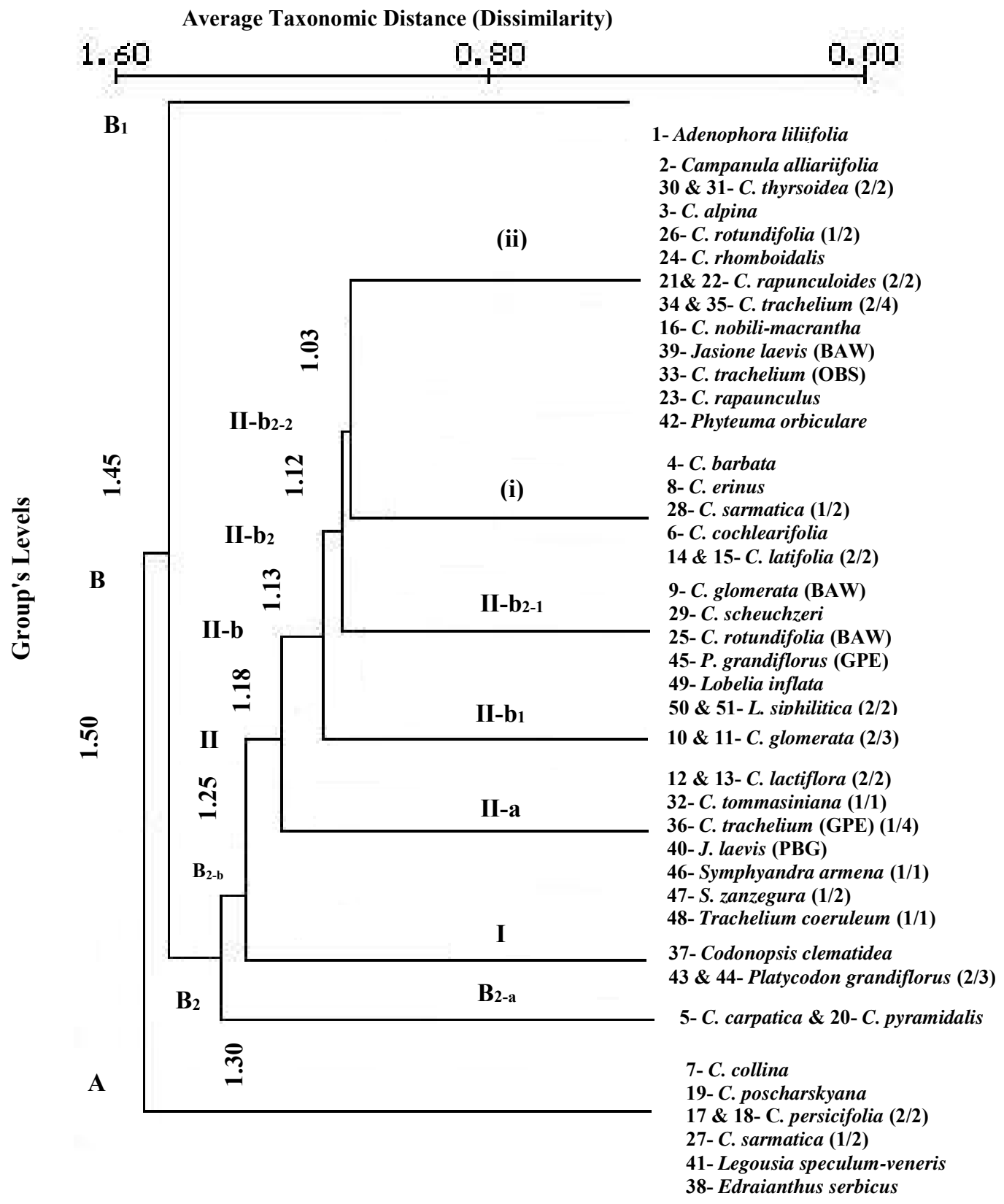

Fig. 2. Simplified phenogram of the studied 51 OTU's of the Campanulaceae. 


\section{Discussion}

According to Barthlott (1981 \& 1990), micro-characters connected with the structure of the anticlinal and periclinal epidermal cell walls are usually of high systematic significance at various taxonomic levels. Most seed coats exhibit a complex and highly diverse morphology, providing valuable taxonomic characters that can be useful for assessing phenetic relationships and delimiting taxa at different levels (Hufford, 1995; Karcz et al., 2000 and Johnson et al., 2004). Variation in seed morphology (overall seed coat pattern or primary sculpture of seed coat epidermal cells) has been stated to be of high taxonomic significance at the generic level and has been used variously in systematic efforts ranging from identification (Sako et al., 2001 and Khalik \& Van der Maesen, 2002) and taxonomic circumscription (Constantinidis et al., 2001 and Mendum et al., 2001).

In the present study, SEM observations of seed surface sculpture were focused on the arrangement of epidermal testa cells (overall seed coat pattern), the curvature, level and thickness of the outer anticlinal walls, the curvature of the outer periclinal walls (primary sculpture) and the fine cuticular ornamentation of the cell walls (secondary sculpture). Although this study is a preliminary one, yet some concluding remarks can be deduced. The constructed phenogram produced by the analysis of 56 attributes of seed morphology, showed that the studied taxa were scattered along the phenogram regardless of the genera included in the study. This finding may give extra support to the concept of the strictly monophyletic nature of the family (Thorne, 1992; Tob \& Morin, 1996; Conser et al., 1994 \& 2004 and Eddie et al., 2003).

The overall pattern of seed coat epidermal cells of the studied taxa showed two distinct morphotypes (reticulate and striate) that often crossed the generic and specific barriers (Table 2 and Plates. 1-4). This finding seems rather natural, as the Campanulaceae include plants with varied life forms and lor morphotypes (Shulkina et al., 2003). The same life form may be present in different tribes and individual tribes may include more than one life form. The same species or lower categories sometimes exhibit various different morphotypes (Tutin, 1976). However, Shulkina et al. (2003) states that for this family in particular, polymorphism may be of minor taxonomic significance and do not correlate with Campanulaceae taxonomic classifications. 
In the present study, Edraianthus serbicus (38) was the sole taxon with pusticulate overall seed coat pattern, consisting of large rhomboid cells with levelled anticlinal walls and flat to convex periclinal walls. In the constructed phenogram, it splitted from the rest of the studied taxa at a high dissimilarity level (3.00). Kamel (2005) found that SDS-PAGE of seed protein profiles supported a relation between Edraianthus serbicus and the following taxa: Symphyandra armena, S. zanzegura, Lobelia inflata and $L$. siphilitica. Shulkina et al. (2003) suggested that Edraianthus is closely related to Campanula and not to genera with apical capsule dehiscence and should be excluded from the sub-tribe Wahlenberginae. However, the present study shows that this taxon is of a relatively distinct and isolated nature and so, its relationships with other genera in the Campanulaceae is in need of more studies.

As for Adenophora liliifolia (1), it is splitted from the majority of the studied taxa (Fig. 1) at the dissimilarity level of 1.38 due to the fact that its seed coat pattern showed a unique scalariform pattern with tangentially elongated rectangular cells with highly uniform buttressed thick anticlinal walls. Kamel (2005) showed that this taxon was highly divergent from the same studied taxa of Campanulaceae $s$. $l$. when testing its seed protein profiles. This finding, in addition to the relatively early splitting of the taxa, Legousia speculum-veneris (41) Trachelium coeruleum (48) and Phyteuma orbiculare (42) from the constructed phenogram, may give an indication that at least, some of these genera may not be closely related to Campanula as was presumed before (Eddie et al., 2003).

Concerning the studied taxa of Campanula (2 - 36), overall seed coat pattern showed the prevalence of the aforementioned two morphotypes (Table 2 and Plates. 1-4). The constructed phenogram based on the coding of 45 attributes of seed shape and outer seed coat micromorphology showed that the studied Campanula taxa were scattered along the phenogram (Fig. 1), C. poscharskyana (19) was unique in possessing geometrically shaped rectangular cells with highly striated to warty anticlinal walls, $C$. rapaunculus (23) possessed a typical sulcate seed coat pattern, C. collina (7) possessed a sulcate pattern with transverse elevated bridge like connections (Plate 2). Moreover, the encountered variations in seed shape and seed coat micromorphology between the different accessions of the same species were sometimes remarkable, leading to either the clustering of the same accessions together at a relatively high dissimilarity level (C. latifolia -14 \& 
-15, C. rapunculoides $-21 \&-22$, C. thyrsoidea $-30 \&-31$, C. lactiflora -12 $\&-13$ ) or the clustering of the different accessions of the same species with other taxa, thus, concerning $C$. trachelium $(33,34,35 \& 36)$, one of its accessions (36) clustered with other Campanula taxa (4, 8, 6, 28 \& 32), at the dissimilarity level of 0.90 .

The other three accessions of $C$. trachelium (33, $34 \& 35)$ clustered together, but separated from each other at a relatively high dissimilarity at 0.60 and 0.48 . The same is true for C. glomerata $(9,10 \& 11)$, where one of its accessions (9), clustered with $C$. scheuchzeri (29) at a dissimilarity of only 0.50 due to their striking similarity in most seed coat aspects (Plate. 2 and Table 2), while the other two accessions (10\& 11) grouped together with a dissimilarity of 0.40 . Also, the two accessions of $C$. rotundifolia ( 25 \& 26) were widely separated in the constructed phenogram, the former accession (25), grouped with most of the studied taxa and splitted at 1.20, while the latter one (26) grouped with $C$. alpina (3) and $C$. rhomboidalis (24) due to their sharing the reticulate to sulcate overall seed coat pattern. The two accessions of $C$. persicifolia $(17 \& 18)$ represented an extreme case, where their seed coat epidermal cells varied greatly. The first accession (17) possessed ruminate overall seed coat pattern, cells with sinuate thin anticlinal walls and flat periclinal walls showing sulcate ornamentation, while the second accession possessed a typical scalariform overall seed coat pattern with relatively thicker anticlinal walls and concave periclinal walls. Tutin (1976) showed that these three species (C. glomerata, $C$. persicifolia, $C$. trachelium and $C$. rotundifolia) possess different very variable and divergent morphotypes, the variants often controversially classified as separate species, subspecies and lower categories. He also cautioned that in some species as $C$. rotundifolia, diagnostic characters are extremely variable, often with little correlation between them .He also points out that in addition to an array of intraspecific taxa, numerous variants are often treated as distinct species.

Kamel (2005) found remarkable variations between the same accessions of the studied Campanula taxa when testing their storage seed protein profiles. Eddie et al (2003) showed that many species have been placed, for convenience, in Campanula L. and this has further complicated the understanding of phylogenetic relationships. In their opinion, the boundaries between the infra generic categories of Campanula are still misleading, with some of these probably deserving a generic status than some of the currently recognized segregate genera. Kovai (2004) stated that Campanula species 
are geographically, edaphically and micro climatically highly specialized and characterized by extensive polymorphism, leading to artificial boundaries between species and lower categories up to the varieties, subvarieties, forms and even subforms. He further pointed that the genus Campanula, in its current circumscription, needs fundamental revision. Thus, the observed variations in the seed shape and sculpture of the seed coat of the studied taxa of Campanula may give extra support to views held by Eddie et al. (2003), Kovai (2004) that the genus Campanula as is currently constituted may be non monophyletic and in need of revision .

Concerning the studied species of Codonopsis (37), seed coat pattern was characterized by a narrowly interwoven network of rhomboid cells with buttressed outer anticlinal walls (Plate 2). This pattern was strikingly similar to one of the accessions of Platycodon grandiflorus (43) and similar to a certain extent to the second accession of Platycodon grandiflorus (44) as regards the presence of buttresses on anticlinal walls and the overall pattern of cells. However, it differed in other aspects as the relatively large cell size and undulated anticlinal walls in Platycodon grandiflorus (44) (Plate 2 and Table 2).

The two accessions of Jasione ( $39 \& 40$ ) clustered together at the dissimilarity level of 1.10 , but showed relationships with most of the studied taxa of Campanula (Plate 3 and Table 2). This finding is in agreement with Sales et al (2002) who showed that the position of Jasione is probably basal andlor somewhat intermediate between Wahlenbergioid and Campanuloid taxa, with more similarities to Campanuloids.

As for Platycodon grandiflorus (43, $44 \& 45)$, one of its accessions (45) clustered with Lobelia species at 0.80 due to their possessing similar ovate to ellipsoid seed shape and smooth anticlinal walls of seed coat epidermal cells, However, this finding may be non significant because the same characters are present in other taxa. The other two accessions grouped together at 0.40 and were shown to have relations with most of the studied taxa. The same finding was shown by Kamel 2005 where seed protein profiles grouped the accessions of Platycodon together, but stressed on its relation to most of the studied taxa. In fact, Platycodon grandiflorus possess distinct morphological features (Heywood, 1993) and more work is still needed on this taxon. 
The relationships of the two studied species of Lobelia $(49,50 \& 51)$ to most of the studied taxa were confirmed in this study (Plates 1-4 and Table 2). Kamel (2005) achieved similar results when investigating the seed protein profiles of the same taxa. These results can favor to some extent the views stating that Lobelia should not be separated from the Campanulaceae in a separate Lobeliaceae (Tobe \& Morin, 1996; Thorne, 1992 and Cronquist 1981 \& 1988). Concerning the remaining taxa Legousia speculum-veneris (41), Phyteuma orbiculare (42), Symphyandra armena (46) S. zanzegura (47) and Trachelium coeruleum (48), the following will be reviewed:

Legousia speculum-veneris (41) possess a generally sulcate overall seed coat pattern. However, this apparently sulcate pattern is in fact an interwoven network of very thick walled cells, reminiscent of the patterns of Codonopsis clematidea (37) and Platycodon grandiflorus (43, $44 \& 45)$ if we imagine the anticlinal cell walls becoming thinner. Kamel (2005) confirmed the aforementioned relation of Legousia speculum-veneris to Platycodon grandiflorus. However, much controversy still surrounds the taxonomy of Legousia (Conser et al., 2004). Phyteuma orbiculare (42) possessed a similarity to a certain extent with many of the studied taxa (Plates 1-4 and Table 2), yet, more conclusive results are still needed. The same applies to Trachelium coeruleum (48) who splitted at an early stage from most of the studied taxa at 1.40 .

As for Symphyandra armena (46) S. zanzegura (47), the two species were shown to possess relationships with most of the studied Campanula taxa (Plates 1-4 and Table 2) Symphyandra have been segregated from Campanula based on the presence of a conspicuous tubular nectariferous disc and connate anthers, respectively. However, seed coat morphology may suggest a still closer relation to Campanula, but more work is still needed.

Finally, the remarkable polymorphism in either the seed shape or seed coat microsculpture within the different accessions of the same species may render this criterion alone, not an adequate one in the delimitation and classification of taxa within the Campanulaceae $s$. $l$. However, this study is only a preliminary investigation; more future work is still needed on the Campanulaceae, its classification, its generic and specific concepts and finally their delimitation. This cannot be achieved except by investigating more cosmopolitan material and utilizing other criteria. 


\section{References}

APG (Angiosperm Phylogeny Group) 2003. An update of the Angiosperm Phylogeny Group classification for the orders and families of flowering plants: APG II. Bot J. Linn. Soc. 141: 399-436.

Barthlott, W. 1981. Epidermal and seed surface characters of plants: systematic applicability and some evolutionary aspects. Nordic $J$. Botany 1: 345-355.

1990. Scanning electron microscopy of the epidermal surface in plants. Pages 69-83 in D. Claugher (ed). Scanning electron microscopy in taxonomy and functional morphology. Clarendon, Oxford.

Belyayev, A.A. 1986. The features of anatomy and surface ultrastructure of the seed coat in some representatives of critical genera of the Campanulaceae family. Bot. Zh. SSSR. 71: 1371-1375.

Boissier, E. 1875. Campanulaceae. In: Flora orientalis 3: 884-962. H. Georg, Geneva and Basel.

1888. Campanulaceae. In: Flora orientalis, suplementum. H. Georg, Geneva and Basel.

Bremer, K. 1994. Asteraceae, cladistics and classification. Timber Press, Portland, Oregon. pp. 36-46.

Buss, C.C., Lammers, T.G. and Wise, R.R. 2001. Seed coat morphology and its systematic implications in Cyanea and other genera of Lobelioideae (Campanulaceae). Amer. J. Bot. 88(7): 1301-1308.

Charadze, A. 1949. A treatment of the systematics of the Caucasian species of the genus Campanula section Medium A. DC. Zametki Sist. Geogr. Rast. 15: 13-33.

1970. On the florogenesis of the Caucasian Campanulas. Zametki Sist. Geogr. Rast. 28: 89-102.

1976. The genus Campanula L. s. $l$. in the Caucasus (Conspectus). Zametki Sist. Geogr. Rast. 32: 45-56.

Constantinidis, T., Psaras, G.K. and Kamari, G. 2001. Seed morphology in relation to infrageneric classification of Consolida (DC.) Gray (Ranunculaceae). Flora 196: 81-100. 
Cosner, M.E., Jansen, R.K. and Lammers, T.G. 1994. Phylogenetic relationships in the Campanulales based on $r b c L$ sequences. Plant Syst. Evol. 190: 79-95.

, Raubeson, L.A. and Jansen, R.K 2004. Chloroplast DNA rearrangements in Campanulaceae: phylogenetic utility of highly rearranged genomes. BMC Evolutionary Biology 4: 27.

Cronquist, A. 1981. An Integrated System of Classification of Flowering Plants. New York. 2nd ed. Bronx.

1988. The Evolution and Classification of Flowering Plants,

DeCandolle, A. 1830. Monographie des Campanulées. V. Desray, Paris.

Eddie, W.M.M. 1997. A Global Reassessment of the Generic Relationships on the Bellflower Family (Campanulaceae). Ph. D. Thesis. University of Edinburgh, Institute of Cell and Molecular Biology.

----------, Shulkina, T., Gaskin, J., Haberle, R.C. and Jansen, R.K. 2003: Phylogeny of Campanulaceae s. str. Inferred from ITS sequence of nuclear ribosomal DNA. Ann. Miss. Bot. Gard. 90: 554-575.

Fedorov, A.A. 1972. Campanulaceae In Flora of the U.S.S.R (Edited by: Shishkin BK). Moskva-Leningrad: Akademia Nauk SSSR, 92-324.

Heywood, V.H. 1993. Flowering plants of the world. Andromeda Oxford Ltd. pp. 254-256.

Hickey, M. and King, C. 1997. Common families of flowering plants. Cambridge University Press, Cambridge, United Kingdom. pp. 136139.

Hong, D.Y. and Pan, K.Y. 1998: The restoration of the genus Cyclocodon (Campanulaceae) and its evidence from pollen and seed coat. Acta Phytotax. Sin. 36(2): 106-110.

Hufford, L. 1995. Seed morphology of Hydrangeaceae and its phylogenetic implications. Int. J. Plant Sci. 156: 555-580.

Johnson, L.A., Huish, K.H and Porter, J.M. 2004. Seed Surface Sculpturing and Its Systematic Significance in Gilia (Polemoniaceae) and Segregate Genera. Int. J. Plant Sci. 165: 153-172. 
Jonsell, B., Jonsell, L. and Tyler, T. 2000. A commentary on Campanula glomerata. Sven. Bot. Tidskrift 94(1): 46-47.

Judd, W.S., Campbell, C.S., Kellog, E.A. and Stevens, P.F. 1999. Plant Systematics. A Phylogenetic Approach Sinauer Associates, Inc. U. S. A. pp. 393-395.

Kamel E.A. 2005. Seed protein diversity and the relationships within the Campanulaceae. Assiut Univ. J. Bot. 34(2): 507-526.

Karcz, J.W, Eiss, H. and Maluszynska, J. 2000. Structural and embryological studies of diploid and tetraploid Arabidopsis thaliana (L.) Heynh. Acta Biol. Crac. Series Botanica 42(2): 113-124.

Khalik, K.A. and Van der Maesen, L.J.G. 2002. Seed morphology of some tribes of Brassicaceae: implications for taxonomy and species identification for the flora of Egypt. Blumea 47:363-383.

Kolakovsky A.A. 1987. System of the Campanulaceae family from the old world. Bot. Zhurnal. 72:1572-1579.

Kovai, S. 2004. The genus Campanula L. (Campanulaceae) in Croatia, circum-Adriatic and west Balkan region. Acta Bot. Croat. 63(2): 171202.

Lakoba, R.V. 1991. Ispol'zovanie priznakov anatomii i ul'trastruktury ploda dlya tselei sistematiki i filogenii kolokol'chikovykh (Campanulaceae). In: Tikhomirov VN ed (s). Filogeniya i sistematika rastenii: mater. 8 Mosk. soveshch. po filogenii rast. Moskva: Nauka pp. 58-60. Rus Anatomy and morphology Abstr. in Ref. Zhurn., Biol. no.2: V 1293. On the use of anatomic and ultrastructural characters of the seed coat in the systematics and phylogeny of Campanulaceae.

Lammers, T.G. 1992. Circumscription and phylogeny of the Campanulales. Ann. Miss. Bot. Gard. 79: 388-413

Lewis, P.E., Andrews, S., Leslie, A.C. and Alexander, C. 1999. The establishment of a national collection of Campanula L. Proceeding of the Third International Symposium on the Taxonomy of Cultivated Plants, Edinburgh, UK, 20-26 July 1998, publ. 2000, pp. 35-38. 
Mabberley, D.J. 1997. The Plant-book: A portable dictionary of the vacular plants $^{2 n d}$ ed: 120-121. Cambridge University Press, Cambridge

Mededovic, S. 1980. Neke odlike hromosomskih komplemenata, polena i sjemenjace Edraianthus dalmaticus DC i Edraianthus tenuifolius (W. K.) DC. (Some characteristics of the chromosome complements, pollen, and seed coat in Edraianthus dalmaticus DC. and Edraianthus tenuifolius (W. K.) DC. God. Biol. Inst. Sarajevu. 33: 113-128.

Mendum, M., Lassnig, P., Weber, A. and Christie, F. 2001. Testa and seed appendage morphology in Aeschynanthus (Gesneriaceae): phytogeographical patterns and taxonomic implications. Bot. J. Linn. Soc. 135: $195-213$.

Murata, J. 1992. Systematic implication of seed coat morphology in Lobelia (Campanulaceae-Lobelioideae). J. Fac. Sci. Univ. Tokyo 15. 155-72.

1995. A revision of infrageneric classification of Lobelia (Campanulaceae: Lobelioideae) with special reference to seed coat morphology. J. Fac. Sci. Univ. Tokyo. Bot. 15(5): 349-371.

Petterson, J.A. 1997. Identity of the original Wahlenbergia gracilis (Campanulaceae) and allied species. An historical review of early collections. New Zealand J. Bot. 35(1): 55-78.

Reveal, J.L. 1999. Selected Families of Angiosperms: Asteridae Campanulales Rchb. f., 1828 PBIO 450 Lecture Notes Norton-Brown Herbarium, University of Maryland, College Park, MD 20742-5815

Rohlf, F.J. 1993. NTSYS-pc, numerical taxonomy and multivariate analysis system. New York. Exeter Publ., Ltd.

Sako, Y., Regnier, E.E. and Daoust, T. 2001. Computer image analysis and classification of giant ragweed seeds. Weed Sci. 49: 738-259.

Sales, F., Hedge, I.C., Eddie, W., Preston, J. and Moller, M. 2004. Jasione L. taxonomy and phylogeny. Turk J. Bot. 28: 253-259.

Schönland, S. 1889. Campanulaceae. In Die NatÅrlichen Pflanzenfamilien, Teil IV, Abteilung 5 (Edited by: Engler, A. and Prantl, K.). Leipzig: Wilhelm Engelmann 1889, 40-70.

Shrestha, K.K. and Kravtsova, T.I. 1992. Anatomiya i ul'trastruktura semennoi kozhury v rode Cyananthus (Campanulaceae) v svyazi s ego 
Systematic implications of seed coat morphology in ...

sistematikoi. (Seed coat anatomy and ultrastructure in the genus Cyananthus (Campanulaceae) in relation to its systematics. Bot. Zhurn. 77(6): 18-29.

Shulkina, T., Gaskin, J. and Eddie, W. 2003 Morphological Studies Toward An Improved Classification of Campanulaceae S. Str. Ann. Miss. Bot. Gard. 90: 576-591.

Stace, H.M. and James, S.H. 1996. Another perspective on cytoevolution in Lobelioideae (Campanulaceae). Amer. J. Bot. 83(10): 1356-1364.

Stearn, W.T. 1966. Botanical Latin. Nelson and Sons. London. Pp. 506-507.

Stephenson, A.G., Good, S.V. and Vogler, D.W. 2000. Interrelationships among inbreeding depression, plasticity in the self-incompatibility system and the breeding system of Campanula rapunculoides $\mathrm{L}$. (Campanulaceae). Rastitel Nye Resursy 36(1): 3-17.

Takhtajan, A.L. 1997. Diversity and Classification of Flowering Plants. Columbia Univ. Press, New York.

Teslov, L.S. 2000. Comparative study of the flavonoid composition of some species of the genus Campanula L. of the series Rapunculoideae Charadze from the section Campanula. Bot. Rev. 58: 225-348.

Thorne, R.F. 1992: Classification and geography of flowering plants. Bot. Rev. 58: 225-348.

Tobe, H. and Morin, N.R. 1996. Embryology and circumscription of Campanulaceae and Campanulales: A review of literature. J. Plant Res. 109 (4): 425-435.

Tu, P.F., Xu, L.S., Xu, G.J. and Namba, T. 1998. Histological studies on the roots of eighteen species of sect. Microdiscus of the genus Adenophora. Acta Pharm. Sinica 33(5): 379-388.

Tutin, T.G. 1976. Campanulaceae In Flora Europaea (Edited by: Tutin, T.G., Heywood, V.H., Burges, N.A., Moore, D.M., Valentine, D.H., Walters, S.M., Webb, D.A.). Cambridge: Cambridge Univ Press, pp. 74-102.

Tyler, T. 1999. Classification and geography of the flowering plants. Sven. Bot. Tidskrift. 93(3): 139-144. 
Werker, E. 1997. Seed Anatomy (in Handbuch der Pflanzenanatomie, vol. Berlin, Stuttgart: X.3.). Gebruder Borntraeger, pp. 424. 